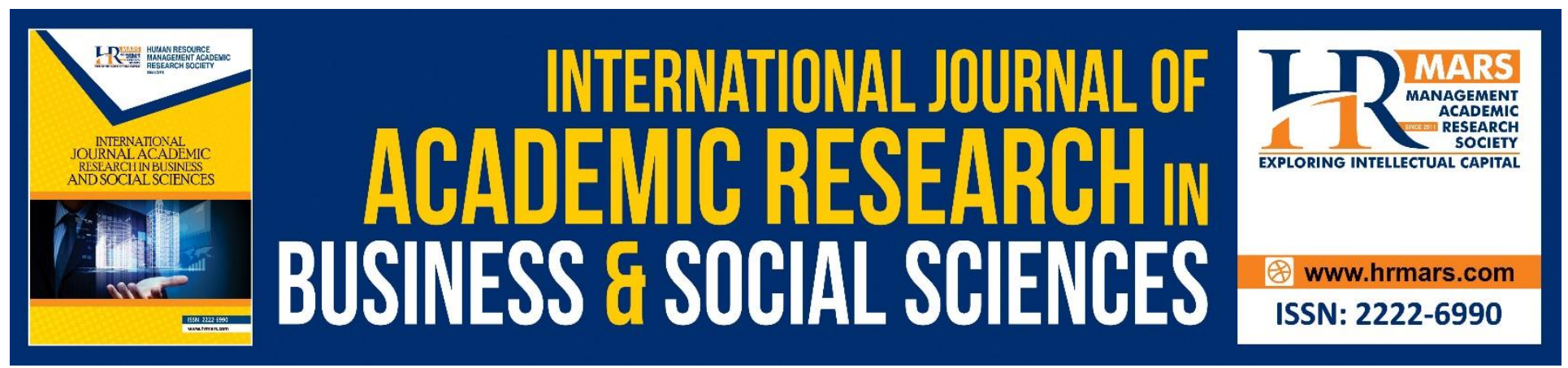

\title{
Intention to Use Online Food Ordering Services Among Universities Students During COVID-19 Pandemic
}

\author{
Noorazlin Ramli, Fatimah Abd Ghani, Wan Nazriah Wan Nawawi, Hayati \\ Adilin Mohd Abd Majid
}

To Link this Article: http://dx.doi.org/10.6007/IJARBSS/v11-i13/8556

DOI:10.6007/IJARBSS/v11-i13/8556

Received: 05 November 2020, Revised: 30 November 2020, Accepted: 19 December 2020

Published Online: 24 January 2021

In-Text Citation: (Ramli et al., 2021)

To Cite this Article: Ramli, N., Ghani, F. A., Nawawi, W. N. W., \& Majid, H. A. M. A. (2021). Intention to Use Online Food Ordering Services Among Universities Students During COVID-19 Pandemic. International Journal of Academic Research in Business and Social Sciences, 11(13), 394-405.

Copyright: (C) 2021 The Author(s)

Published by Human Resource Management Academic Research Society (www.hrmars.com)

This article is published under the Creative Commons Attribution (CC BY 4.0) license. Anyone may reproduce, distribute, translate and create derivative works of this article (for both commercial and non-commercial purposes), subject to full attribution to the original publication and authors. The full terms of this license may be seen

at: http://creativecommons.org/licences/by/4.0/legalcode

Special Issue: Beyond 2021 and COVID-19 - New Perspective in the Hospitality \& Tourism Industry, 2021, Pg. 394 - 405 http://hrmars.com/index.php/pages/detail/IJARBSS JOURNAL HOMEPAGE

Full Terms \& Conditions of access and use can be found at http://hrmars.com/index.php/pages/detail/publication-ethics 


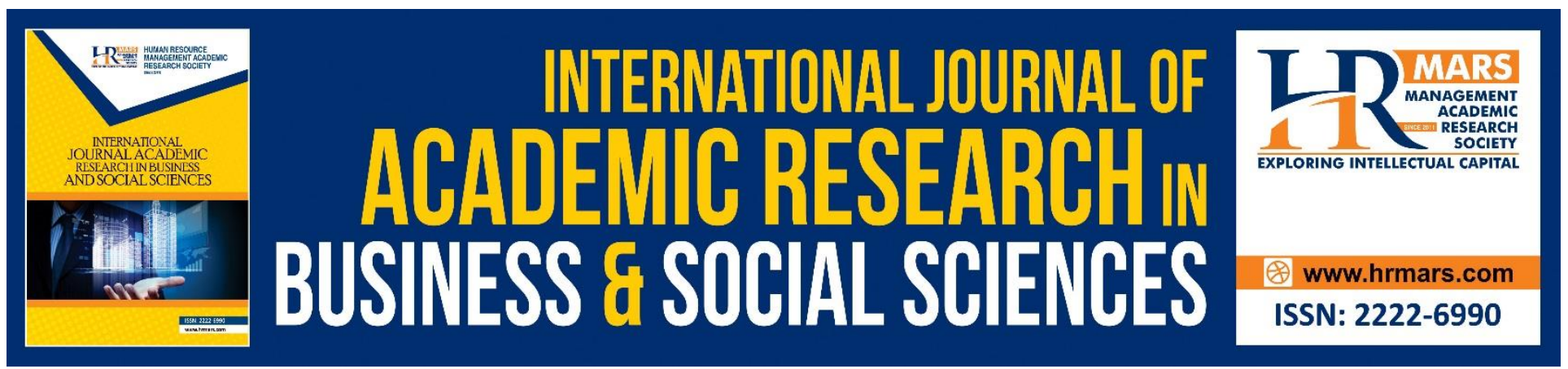

\title{
Intention to Use Online Food Ordering Services Among Universities Students During COVID-19 Pandemic
}

\author{
Noorazlin Ramli ${ }^{1}$, Fatimah Abd Ghani ${ }^{1}$, Wan Nazriah Wan Nawawi ${ }^{1}$, \\ Hayati Adilin Mohd Abd Majid ${ }^{2}$ \\ ${ }^{1}$ Faculty of Hotel and Tourism Management, Universiti Teknologi MARA Cawangan \\ Terengganu Kampus Dungun, Malaysia, ${ }^{2}$ Faculty of Hotel and Tourism Management, Universiti \\ Teknologi MARA Cawangan, Terengganu Kampus Chendering, Malaysia
}

\section{Abstract}

The purpose of this paper is to determine the students' behavioural intention to use electronic food ordering in Kuala Terengganu. The quantitative method was applied through an online questionnaire survey distributed to randomly selected respondents in two universities in Kuala Terengganu, and 362 online questionnaires were completed and returned with reliable and meaningful results. The result clearly shows that the majority of the students have a positive intention to use electronic food ordering services due to perceived convenience, customer control, attractive marketing, and eagerness to use technology during Covid-19. Besides, they feel that electronic food ordering is user-friendly, and they can get sufficient information to order. Therefore, this study is vital in providing knowledge and information to the food industry player in identifying all the advantages of having an online ordering system during the pandemic. In line with that, online ordering is the only source of revenue for local food businesses by helping them from permanent closures during this challenging time and take advantage of electronic food ordering as one of their long-term marketing strategies.

Keywords: Online Food Ordering, Electronic Food Ordering, Behavioural Intention to Purchase, Covid19.

\section{Introduction}

Most businesses have affected with the recent pandemic situation of the coronavirus outbreak globally. The coronavirus pandemic gives a significant impact to the business sectors as most of them encounter financial problems (Abd Hadi et al., 2020). The nature of traditional business has been transformed drastically due to Covid-19 pandemic, and all sectors of business have been affected. This global challenge had spread alerts among people, and most of them avoid interacting with others 
(Bhatti et al., 2020). In the new era especially in this new norm, technology has changed the world into a new phenomenon by adjusting human behaviour into a modern way that causes people effortless from waking up in the early morning until getting work as well as providing food (Kandasivam, 2017). Therefore, the ordering process has gone through a new channel as technology growth. Electronic food ordering system is a food ordering process by using online, mobile, and text message to make an order. The food ordering application that uses E-Commerce allow customers to place orders just via one click on the internet (Kashid et al., 2020; Das, 2017).

This research has been supported by Prabowo and Nugroho (2017), who mentioned that premium customer is spending more money toward good service provided. Thus, it shows that people nowadays are willing to pay more for any high-quality service available that requires less time consuming and energy. It is happening due to the phenomena of competition in the workplace that need people to focus more on their work to survive. Modern technology makes the electronic food ordering available to use at any food establishment like restaurant and cafeteria at the college campus. It is stated by wise Silva et al. (2016) that the current trend of restaurant and cafeteria at college campuses allowing people to order food by using electronic devices or internet connection.

In addition, according to Statista Portal (2017) for global comparison, China is the country that shows the largest revenue generate in 2018 with US\$ 48,530. Other than that, the segment of "Online Takeaway" reach until USD41,937 million, and it is the largest contribution towards market volume in China. Besides, the revenue of "Online Takeaway' in Malaysia is US\$353 m for the year of 2018. Thus, this shows that the demand from people nowadays is more to online takeaways. Besides, the entrepreneurs and foodservice operators in Kuala Terengganu take this opportunity to offer this type of service at their restaurant to be different from others and increase in sales.

Moreover, the online ordering system allows the users to custom-make their order without misunderstanding with the employee (Chorneukar, 2014). For instance, if customers make an order at the counter, and the waiter wrongly clicks or writes the menu, it will cause a delay in service hence lead to dissatisfaction. Other than that, Das (2017) revealed that customers choose electronic food ordering due to the precision of order. Customer may review all orders and make changes before submit and proceed to payment. Due to that, it is safer than traditional food ordering method by verbally at the restaurant. This study generally would contribute to multiple perspectives on academic research and practical implementation. Current online marketing strategies should be beneficial due to the change scenarios of businesses upon and after Covid-19 outbreak.

\section{Problem in Context}

Electronic or online food ordering is one of the technologies that has been developed to ease the food business. It is believed that consumers can now purchase the goods and services anywhere, anytime in seven days a week, without thinking of the geographical factors, and money available in hand. Given the changing scenarios, restaurant businesses that are not switching over to electronic food ordering are always missing out on some great opportunities to grow their business exponentially. By adopting new technology in the business, the lives of the customers could be simplified, thus ensure the business is able to compete in the market. 
Due to covid-19 outbreak and lockdown, small restaurants and businesses are both affected during and in the aftermath of the outbreak. The small restaurants and businesses have shut down temporarily in response to COVID-19 until a permanent closure is inevitable. Due to this, food delivery services have been seen as the saviour for most restaurants to stay resilience during this pandemic. The online ordering system can be seen as a vital necessity among the restaurant industry and food business in the current situation. In this era of digitalisation, people have moved on from the traditional ordering method to online ordering because it is easy, error-free, quick, and completely transparent (Kwong, 2017). If the restaurant is unable to take advantage of this revolutionary shift in the trend, they will miss out on this huge financial opportunity. Besides, it was reported that customers could order food online because it's convenient, and those with smartphones can order food virtually. Moreover, by adapting the online food ordering system in the business, clients will be given the flexibility to place the orders outside the business hours whenever it is the most convenient for them.

Furthermore, the transition to online ordering in the business could give advantage to the management in handling their customers and order. An online ordering system for business helps to enrich the customer-business relationship. The restaurants can develop connections with customers through online delivery during this crisis, and they can continue during post-pandemic as well. By using the online ordering system, the customer's contact information and detailed order history could be easily captured. Thus, marketing campaigns such as sending promotions and offering discounts to loyal customers could be applied to the business in encouraging repeat orders.

Next, the restaurant operators who are not adopting online ordering will face problem in updating information in their menu card. As the restaurant did not apply electronic food ordering, the restaurant manager needs to develop a menu card as a reference for customers, which is more costly. Conversely, by online ordering, it is much easier and considerably cheaper to create and maintain a great-looking menu that will make customers attracted to order. Besides, by integrating online ordering into the POS system, changes can be made on the go and be automatically synced online. Thus, this will end up saving precious time and money and ensures that customers are getting up-todate business offerings and promotions.

Furthermore, using an online ordering system is the easiest way to reach millennials (people under 30) who are the most critical targeted audiences for most business players in the foodservice industry. Kwong (2017) stated that over $97 \%$ of millennials actually using their phones for online ordering, and probably make them as the most essential and sales-generating target audience. Nevertheless, even the most traditional customers have also been forced to explore the online purchasing and ordering services during the Covid-19 outbreak. Thus, restaurant businesses and the food industry can easily reach out the newer demographics and target market on those who have not migrated into using online services before the pandemic by providing online deliveries.

Overall, implementing an online ordering system can give advantages to the restaurant business during and after the Covid-19 pandemic. It has been proven that setting up an online ordering system encouraging restaurant for steady business growth and revenue. However, implementing an online ordering system coupled with effective customers' data on the intention for 
food ordering services will bring the business to be more outstanding in the marketplace. Thus, this study is important to highlight the customer, particularly students' behavioural intention of electronic food ordering as it is the way in boosting restaurants' stream of revenue prior to the challenging situation.

\section{Literature Review}

In Malaysia, the food delivery system has just begun actively for the past few years. This can be seen with the existing of Foodpanda, DeliverEat, and Uber Eats. According to Kwong (2017), "online food ordering system is a comprehensive self-service system where it allows the customers to control over their pace of ordering hence limiting the amount of personal interactions they encounter". The trends of online purchase market in Malaysia was projected at around RM1.8 billion in 2013, and, by 2015, it is expected to expand to RM5 billion (Yeo et al., 2017). The study also stated that purchasing online is one of the reasons why Malaysians gain access to the internet. The consumer preference has also changed as the technology has pushed them to buy everything online, including getting raw items, cooked foods and other items delivered to their home (Kwong, 2017). Almost every business has been shut down during the pandemic Covid-19, and people are stressed to stay in homes. Malaysia also affected by the disturbing situation as the country has been put under lockdown and restrictions have been imposed on going out homes, attending crowded occasions and shopping in markets. People were not allowed to buy food products in the markets; hence online shopping is one and only option (Hasanat et al., 2020).

\section{Perceived Convenience}

According to Lee et al. (2017), perceived convenience of online food ordering in E-Commerce also leads to customer satisfaction and technology adoption. In addition, convenience has been one of the most important attributes of customer motivations to adopt online purchasing (Silva et al., 2016). As a result, customer allocates less time compared to the traditional way. In further, Lee et al. (2017) reported that restaurant owners really care about millennial because their collective purchasing power will exceed $\$ 3.39$ trillion for upcoming years as they love convenience almost as much as they love their smartphones and gadgets.

\section{Customer Control}

In this study, customers are gaining their purchasing power to buy online via the electronic channel or through the availability of the internet. Younger consumers are more likely to use electronic ordering than the older aged group of customers. In addition, the efficient and convenient self-service ordering systems give consumers significant control over their transaction and allow them to limit the amount of personal interaction they encounter. Furthermore, since the customers have control in purchasing anything they desired, Das (2017) stated that the responsibility is on the customers to get their order right and there is no opportunity to misunderstand them on the phone.

\section{Marketing}

According to Rezaei (2016), the usage of attractive visual designs that are easy to navigate regardless of format and he added that the designs should naturally draw the viewer's gaze to the menu offerings hence encourage add-ons. By using this method, it overcomes the disadvantages of 
the traditional queuing system (Adithya et al., 2017). In addition, the restaurant owners will think the marketing strategies that will make their brand more appealing than the other competitors in the online business. According to Silva et al. (2017), customers do not just buy because of the taste; they buy with their eyes.

\section{Eagerness to Use Technology}

Some customers are hesitated to use online ordering because of the fear in making mistakes during the process of ordering over the network or internet. According to Chorneukar (2014), the communication breakdown could be eliminated as the consumer is able to customise their order as the way they like it without having difficulties between the consumers and the person taking the order. In order to reduce this anxiety, the basic steps for ordering process should not be too much different from the advanced steps. The most important thing is the way the order is taken. It must be easy for the consumers and thus give frequent assurances that the order has been received. Besides, the essential elements in the online ordering system is the accuracy of the items being ordered, and the order will be delivered as promised (Weng \& Chao, 2013). Once the online ordering system is easy and efficient, it will inspire the customers to use electronic ordering regularly.

\section{Methodology}

This cross-sectional online survey was conducted in the third week of the MCO. The targeted sample size is 500 . Since it is not feasible to conduct a systematic nationwide sampling, the data was collected online by using Survey Monkey platform. The call for participation was made on social media.

\section{Recruitment Procedures}

The quantitative method has been found to be the most appropriate method for this study. Thus, the online questionnaire survey is developed to evaluate the behavioural intention to use electronic food ordering among universities students in Kuala Terengganu during the Covid-19 pandemic. Kuala Terengganu is targeted for the purpose of the study. First, Kuala Terengganu is a city, the administrative capital, royal capital, and the centre economic of Terengganu. Secondly, Kuala Terengganu has experienced rapid development nowadays in parallel with other major cities in Terengganu (Wan Nawawi et al., 2017). Besides, lack of in-depth or empirical investigation or publication of such a study in Malaysia has meant the present study, which uses Kuala Terengganu as a location hence this will act as a benchmark and basis for other researchers to look at larger perspectives in the near future (Weng \& Chao, 2013). This study might be a fundamental basis for further research to be replicated in the same situational area of study.

With regard to this statement, the universities in Kuala Terengganu have been chosen and the universities students are the main targeted respondents. Apart from that, the only two universities chosen are Universiti Sultan Zainal Abidin (UniSZA) and Universiti Teknologi Mara (UiTM). Owing to the large population in Kuala Terengganu area, it would be difficult for the researchers to survey the whole population. However, according to Salkind (2003), studying a sample rather than the entire population is likely to lead to a more reliable result. Based on this statement, simple random sampling is the most appropriate for this study. Furthermore, this sampling design also offers the most generalised ability and has the least bias (Sekaran, 2000). Given that consideration, all students from 
both universities participated as respondents in the questionnaires distributed. The students involved are from various courses and semesters. An online questionnaire was sent to 500 universities students during MCO (April 1st-15th), and it was completed by 362 respondents. All of the data were used and analysed by using Statistical Package for the Social Science (SPSS) version 20.0.

It has been proven that millennials ( 30 years old and below) particularly students who actually used their phones for online ordering and probably they are the most important and sales-generating targeted audiences (Lee et al., 2017). However, this study only undertook two universities in Kuala Terengganu due to time constraints during MCO. Several strategies have been utilised to reach respondents as many as possible within two weeks of the data collection period. The data collection relied on the personal networks of the researchers assisted by students' universities leaders (MPP) to share the survey. The platforms employed in distributing this survey were social media (Facebook, Twitter and Instagram) and WhatsApp. Meanwhile, Facebook and WhatsApp were reported as the most common communication and social platforms used in Malaysia (Malaysian Communications and Multimedia Commission, 2018). The survey was distributed via WhatsApp and social media postings using standardised general description in dual languages, both English and Malay language versions of the questionnaire.

\section{Result and Analysis \\ Demographic Profiles}

A total of 362 respondents participated in the study. Majority of the respondents $(61.5 \%)$ were male, and the other 38.5 per cent (38.5\%) were female. Besides, most of the respondents (62.4\%) were between 18 and 21 years old. 65.4 per cent (65.4\%) of the respondents were studying Degree; meanwhile, another 32.7 per cent $(32.7 \%)$ of the respondents were studying diploma level. Furthermore, 1.9 per cent $(1.9 \%)$ of the respondents were postgraduate's student.

\section{Students' Behavioural Intention to use Electronic Food Ordering}

A total of sixteen questions were used to measure the respondent's behavioural intention to use electronic food ordering during Covid-19 pandemic. Majority of the respondents are strongly agreed with the statement in the questionnaires given. Thus, this gives a meaningful positive result. Most of the questions appeared to have strongly agreed results, which mean that they have a very strong agreement with the given statement. This is in line with the magnitude of mean scores given on the statement that the respondents were ordering food online because it allows them to initiate a transaction whenever they choose during lockdown (Item 1, $m=4.40$ ). Similarly, respondents seem to strongly agree with the statement that they value the ability to initiate the transaction from the comfort of home, and they are feeling safer (Item 2, $m=4.00$ ). Commonly, students are facing time constraint as busy with online assignments and projects during MCO hence with the existing online ordering would allow them to make quick order and transaction. In addition, the respondents robustly agreed that electronic ordering let them order food without leaving home (Item $3, \mathrm{~m}=4.16$ ). Besides that, the respondents also have a strong agreement about the statement that online ordering allows them to initiate a transaction at a convenient time during lockdown (Item 4, m = 4.18). 
Moreover, online ordering also allowing the participants to be in charged (Item 5, $\mathrm{m}=3.96$ ) as the students have their preference on the type, quantity, and size of the item they wanted to buy. Results showed that some students agreed with online ordering as to fulfil the order that has been made (Item 6, $m=4.04$ ). Additionally, the respondents have an agreement on online ordering that gives them more control over the food that they ordered for delivery or takeout during MCO (Item 7, $m=4.00)$. Thus, they are confident to use online ordering than traditional method during Covid-19 pandemic (Item $8, \mathrm{~m}=4.16$ ).

On the other hand, the respondents also agreed that online advertisement has more attractive visual designs (Item $9, \mathrm{~m}=3.60$ ) and they are attracted to use online ordering (Item $10, \mathrm{~m}$ = 3.81). The respondents also have a firm agreement about the statement that online ordering has better marketing strategy (Item $11, \mathrm{~m}=4.04$ ) hence they choose online ordering because they agreed that the marketing is more appealing than traditional marketing strategy (Item $12, \mathrm{~m}=4.00$ ). In addition, the respondents used online ordering because they love technology (Item $13, \mathrm{~m}=4.16$ ). This is due to many students nowadays are more familiar to become a technology user (Item 14, $\mathrm{m}=$ 3.68). Besides, the respondents agreed that they simply could save orders, make customisation, and reorder food in seconds by using online ordering in the new norm (Item 15, $\mathrm{m}=3.81$ ). Table 1 shows the descriptive statistic for students' behavioural intention to use electronic food ordering during a pandemic outbreak

Table 1: Descriptive Statistic for students' behavioural intention to use electronic food ordering

\begin{tabular}{|c|c|c|c|}
\hline Construct & Item & Mean (m) & S.D \\
\hline \multirow[t]{4}{*}{$\begin{array}{l}\text { Perceived } \\
\text { Convenience }\end{array}$} & $\begin{array}{l}\text { Online ordering allows me to initiate a transaction } \\
\text { whenever I choose during the lockdown }\end{array}$ & 4.40 & 0.952 \\
\hline & $\begin{array}{l}\text { I value the ability to initiate the transaction from the } \\
\text { comfort of home }\end{array}$ & 4.00 & 0.974 \\
\hline & $\begin{array}{l}\text { I like the ability to order food without leaving home, } \\
\text { and I feel safe }\end{array}$ & 4.16 & 0.911 \\
\hline & $\begin{array}{l}\text { Online ordering allows me to initiate a transaction at } \\
\text { a convenient time. }\end{array}$ & 4.18 & 0.918 \\
\hline \multirow{4}{*}{$\begin{array}{l}\text { Customer } \\
\text { Control }\end{array}$} & Online ordering lets the customer be in charge. & 3.96 & 0.803 \\
\hline & $\begin{array}{l}\text { While using online ordering, I am really sure that the } \\
\text { items submitted for ordered will fulfil what I want. }\end{array}$ & 4.04 & 0.912 \\
\hline & $\begin{array}{l}\text { Online ordering gives me more control over the food } \\
\text { that I order for delivery or takeout }\end{array}$ & 4.00 & 0.876 \\
\hline & I feel in control using online ordering. & 4.16 & 0.813 \\
\hline \multirow[t]{3}{*}{ Marketing } & $\begin{array}{l}\text { Advertisement on online have more attractive visual } \\
\text { designs }\end{array}$ & 3.60 & 0.964 \\
\hline & $\begin{array}{l}\text { Advertisement on online attracts me to use online } \\
\text { ordering }\end{array}$ & 3.81 & 0.907 \\
\hline & Online ordering has a better marketing strategy & 4.04 & 0.912 \\
\hline
\end{tabular}


INTERNATIONAL JOURNAL OF ACADEMIC RESEARCH IN BUSINESS AND SOCIAL SCIENCES

Vol. 11, No. 13, Beyond 2021 and COVID-19 - New Perspective in the Hospitality \& Tourism Industry. 2021, E-ISSN: 2222-6990 @ 2021 HRMARS

I choose online ordering because it is more appealing $4.00 \quad 0.876$

than the conventional services

\begin{tabular}{llcc}
\hline $\begin{array}{l}\text { Technology } \\
\text { Eagerness }\end{array}$ & I use online ordering because I love technology & 4.16 & 0.813 \\
& $\begin{array}{l}\text { I use online ordering because it is familiar to me } \\
\text { I simply can save my orders, customisation and }\end{array}$ & 3.68 & 0.886 \\
& $\begin{array}{l}\text { reorder food in seconds by using the online ordering } \\
\text { services } \\
\text { I use online ordering because it can be paid via the } \\
\text { app and I can earn rewards }\end{array}$ & 0.907 \\
\hline
\end{tabular}

\section{Conclusion}

The research findings obviously showed the positive results of students' behavioural intention to use electronic food ordering during the Covid-19 pandemic. From the findings, the students from Universiti Teknologi Mara (UiTM) Terengganu Campus and Universiti Sultan Zainal Abidin (UniSZA) Campus have a positive intention to use electronic food order due to the perceived convenience, perceived customer control, attractive marketing strategy, and the eagerness of using technology. The findings indicate that restaurant operators should focus on giving their customers higher levels of perceived convenience and control since these factors are associated with a higher intent to use online ordering among consumers precisely students in the new norm of pandemic Covid-19.

This study has shown that perceived convenience is significant for students to use online food ordering during this challenging time. Increased perceived convenience leads to greater satisfaction with online food ordering and a higher likelihood to recommend online ordering to others. Due to that, the restaurant operator and food industry players need to consider the needs and demands of students; and ensure that the electronic ordering system is easy to use, convenient and completely transparent. The apps and system used must be customer-friendly online ordering system with a clear guideline feature so that new customers can automatically use the system like "regulars". Moreover, the restaurant operators can let the customers save their history of orders and just click a button to repeat order in increasing customers' perceived convenience. Other than that, the ability of the system to save their address and payment preferences can also increase the perceived of convenience and safe for online purchase. In addition, the findings showed that an increased level of control leads to high intention to use online ordering. The high level of customer control leads to greater customer satisfaction and higher intent to use or recommend the service to others. The restaurant operators may increase perceived control of online ordering by offering choices. Hence the customers are easily customising their order, select their payment method, and they can decide their delivery options. Besides, the restaurant operators should ensure that their online ordering system is always safe, secure, and items delivered as promised to increase the perceived of control among customers.

Furthermore, the respondents have positive feedback on marketing as it affects their intention to use online food ordering during Covid-19. Electronic or online marketing is believed to be more costeffective than the traditional method and can help restaurants to target a wider audience. The marketing in social media can significantly boost word-of-mouth referrals, thus increase 
recommendation to use the service to others. It is clearly believed that students who are millennial made up the majority of those who are more likely to buy foods online. They choose online ordering because it is more appealing than a traditional marketing strategy and the advertisement online has more attractive visual designs. This means that even customers who are loyal to traditional brick and mortar business method will be attracted to buy online as the visual content is attractive and eyecatching by nature. Videos and images can get customers to stop, look, and watch. Additionally, visual social media platforms such as Snapchat, Instagram, and Pinterest are on the rise, especially amongst students and millennial. So, the intention to use online ordering will be increased as they feel that online marketing and advertisement used are more attractive and interesting.

Additionally, eagerness to use technology among millennial and students could affect the intention to use online ordering. Students and millennials seem to love technology because it is familiar to them rather than baby boomers. The restaurants' operators and companies with online delivery options will get advantages due to millennial are said to be three times more likely to order food at home than their parents. Due to their eagerness to use technology, they are choosing online ordering, which it simply can save their orders, make customisation, and reorder food in seconds. While traditional shopping becomes tough during this challenging situation or may even be scary, consumers are gradually apt to shop online. The consumers are already accepting online retailers with open arms and make this transition significantly easier. More than anything else, this study contributes to the food industry, especially to the food operator and industry players by providing some knowledge about the significance of the growing importance of E-commerce during the outbreak and in postCovid-19. Due to quarantine, the trends in purchasing behaviour has changed due to the rapid growth of mobile devices and apps that making it easier than ever to browse and shop online.

In conclusion, students will continue to use E-commerce as they appreciate the convenience of online shopping during the pandemic. Even if the quarantine session ends, students will be cautious, and they still prefer shopping home or college as this is actually a long-term trend that likely to continue during post-pandemic in future. In order to make use of this, the industry players need to grasp great opportunity to connect with students in engaging social media advertisements, flexible marketing strategies, and convenient omnichannel solutions. In summary, the present study able to provide a comprehensive finding to proof that behavioural intention to use online electronic food ordering reasonably popular among students and the perceived convenience associated with electronic ordering is the most important factor among students.

\section{Corresponding Author}

Noorazlin Ramli. Faculty of Hotel and Tourism Management, Universiti Teknologi MARA Cawangan Terengganu Kampus Dungun.

Email: noora115@uitm.edu.my

\section{References}

Adithya, K. (2017). Online food ordering system. International Journal of Computer Applications. Retrieved from March 15, 2018, from https://www.ijcaonline.org/archives/volume180/number6/28805-2017916046. 
Chorneukar. (2014). To Study the Customer Perceptions of Electronic Food Ordering. Bangalore: St. Joseph's Evening College - Pondicherry University.

Bhatti, A., Akram, H., Muhammad Basit, H., Khan, A. U., Raza, S. M., Naqvi, \& Bilal, M. (2020). Ecommerce trends during COVID-19 pandemic. International Journal of Future Generation Communication and Networking, 13(2), 1449-1452.

Das, J. (2017). Consumer Perception Towards 'Online Food Ordering and Delivery Services': An Empirical Study. Journal of Management (JOM), 5(5), 155-163.

Hasanat, M. W., Hoque, A., Shikha, F. A., Anwar, M., Hamid, A. B. A., \& Tat, H. H. (2020). The Impact of Coronavirus (Covid-19) on E-Business in Malaysia. Asian Journal of Multidisciplinary Studies, $3(1), 8590$.

Kandasivam. (2017). Competition, demand, changing behaviour make food delivery the new normal. Retrieved April 12 from https://www.digitalnewsasia.com/startups/competition-demandchanging-behaviour-make-food-delivery-new-normal.

Kashif, M., Rehman, A. U., \& Javed, M. K. (2020). COVID-19 Impact on Online Shopping. International Journal of Medical Science in Clinical Research and Review, 3(04), 325-330.

Kimes, S. E. (2011). Customer perceptions of electronic food ordering [Electronic article]. Cornell Hospitality Report, 11(10), 6-15.

Kwong, G. S. (2017). Outsourcing to online food delivery services: Perspectives of F\&B business owner. Journal of Internet Banking and Commerce. Retrieved from March 20, 2018, from http://www.icommercecentral.com/open-access/outsourcing-to-online-food-deliveryservices-perspective-of-fb-business-owners.pdf

Lee, E., Lee, S., \& Jeon, Y. (2017). Factors influencing the behavioral intention to use food delivery apps. Social Behavior and Personality: An international journal, 45, 1461-1474.

Malaysian Communications and Multimedia Commission. (2018). Internet users survey 2018: statistical brief number twenty-three. Retrieved from https://www.mcmc.gov.my/skmmgovmy/media/General/pdf/Internet-Users-Survey-2018.pdf

Mohamad A. H., Hamzah, A. A., Ramli, A. A., \& Fathullah, M. (2020). E-Commerce Beyond the Pandemic Coronavirus: Click and Collect Food Ordering. IOP Conference Series: Materials Science and Engineering. 2nd Joint Conference on Green Engineering Technology \& Applied Computing 2020. 864 (2020) 012049 IOP Publishing. https://doi.org/10.1088/1757899X/864/1/012049

Prabowo, G. T., \& Nugroho, A. (2017). Factors that Influence the Attitude and Behavioral Intention of Indonesian Users toward Online Food Delivery Service by the Go-Food Application. Journal of Advances in Economics, Business and Management Research, Atlantis Press, 72, 204-210.

Rezaei, S. S. (2016). Determinants of App Stores Continuance Behavior: a PLS path modelling approach. Journal of Internet Commercial, 408-440.

Roscoe, J. T. (1975). Fundamentals research statistics for the behavioral sciences (2nd Ed.). New York.: holt, Reinhart and Winston.

Salkind, N. J. (2003). Exploring research (5th Ed.). New Jersey: Prentice Hall.

Sekaran, U. (2000). Research methods for business (3rd Ed.). New York: Wiley \& Sons.

Silva, F. Q., Freire, O., Lima-Filho, D. O., Brandão, M. M., Isabella, G., \& Moreira, L. B. (2016). Intentions to purchase food through the internet: developing and testing a model. British Food Journal, 3(118), 572-587. 
Statista Portal. (2017). Food delivery. Retrieved from March 5, 2018, from https://www.statista.com/outlook/374/117/food-delivery/china\#contentlist

Nawawi, W. N., Khalid, S. A., Ramli, N., \& Mohd. Daud, N. (2017). Attitude and Expectation: Food Waste Recycling as a Business Opportunity in Terengganu, Social Sciences \& Humanities, 25, 65-74.

Weng, T. S., \& Chao, I. C. (2013). Evaluating Factors Influencing the Intention to Use Online Ordering System-A Case Study of Lunch Box Purchasing. Journal of Contemporary Management.

Yeo, V., Goh, S. K., \& Rezaei, S. (2017). Consumer Experiences, Attitude, and Behavioral Intention toward Online Food Delivery Services. Journal of Retailing and Consumer Services, 150-162. 